\title{
TRABAJADORAS(ES) DE LA EDUCACIÓN SUPERIOR Y REPRODUCCIONES DE GÉNERO ${ }^{\mathrm{i}}$
}

\author{
Jenny Reyes*
}

\section{HIGHER EDUCATION WORKERS AND GENDER REPRODUCTIONS}

ABSTRACT

This article presents the results of a study on the perception of the teachers of the Faculty of Educational Sciences at Playa Ancha University in relation to the reproduction of gender inequalities in higher education during the years 2004 and 2005. According to the findings of this study, Playa Ancha University is a space that reproduces the differences in gender resulting in inequalities which are reflected on the different segments of this social and cultural universe.

Key words: gender, higher education

* Docente de la Facultad de Ciencias de la Educación, Universidad de Playa Ancha, Chile. Contacto: jereyes@upa.cl

i Percepción de docentes de carreras de Pedagogía de la Universidad de Playa Ancha de Ciencias de la Educación. 